\title{
Potential of bamboo species for the production of briquettes ${ }^{1}$
}

\author{
Martha Andreia Brand ${ }^{2}$, Ailton Leonel Balduino Junior ${ }^{3}$,
} Daniela Leticia Nones ${ }^{2}$, Angela Zakostelsky Neves Gaa ${ }^{2}$

\section{ABSTRACT}

Bamboo is a versatile plant that is widely used in many areas for feeding, manufacturing of utensils, construction and environmental purposes. The energetic use of bamboo stalks or residues from other applications is a promising alternative and compatible with sustainable development principles. This study aimed to evaluate the potential of four bamboo species (Bambusa vulgaris, Phyllostachys bambusoides, Phyllostachys edulis and Phyllostachys nigra) for briquette production. The following properties were evaluated: moisture content, bulk density, compression strength, proximate analysis, gross calorific value and energetic density. The results showed numbers ranging from $1.109 \mathrm{~g} \mathrm{~cm}^{-3}$ to $1.228 \mathrm{~g} \mathrm{~cm}^{-3}$ for bulk density, $4.68 \mathrm{MPa}$ to $5.82 \mathrm{MPa}$ for compression strength, $79.01 \%$ to $82.25 \%$ for volatile content, $15.26 \%$ to $20.18 \%$ for fixed carbon content, $0.38 \%$ to $2.49 \%$ for ash content, $4,571 \mathrm{kcal} \mathrm{kg}^{-1}$ to $4,716 \mathrm{kcal} \mathrm{kg}^{-1}$ for gross calorific value and $5.08 \mathrm{Gcal} \mathrm{m}^{-3}$ to $5.84 \mathrm{Gcal} \mathrm{m}^{-3}$ for energetic density. The briquettes produced from $P$. nigra presented the best energetic quality, followed by briquettes from $P$. edulis, $P$. bambusoides and B. vulgaris. Overall, it may be said that the four bamboo species can be used as alternative raw materials for energy generation.

KEYWORDS: Bambusa vulgaris, Phyllostachys bambusoides, Phyllostachys edulis, Phyllostachys nigra, renewable fuels.

\section{INTRODUCTION}

Bamboo is a versatile plant widely used in many traditional applications, including edible sprouts, toothpicks, handmade baskets and mats, tools, musical instruments and works of art, horticultural sticks, erosion control and soil protection, building material and fuel (Van Dam et al. 2018).

\section{RESUMO}

Potencial de espécies de bambu para a produção de briquetes

O bambu é uma planta versátil e amplamente utilizada na alimentação, fabricação de utensílios, construção civil e usos ambientais. O uso energético dos colmos ou resíduos de outras aplicações é uma alternativa cada vez mais promissora e compatível com os princípios do desenvolvimento sustentável. Objetivouse avaliar o potencial de quatro espécies de bambu (Bambusa vulgaris, Phyllostachys bambusoides, Phyllostachys edulis e Phyllostachys nigra) para a produção de briquetes. Avaliaram-se o teor de umidade, densidade aparente, resistência à compressão, composição química imediata, poder calorífico superior e densidade energética. Os briquetes tiveram densidade aparente variando de $1,109 \mathrm{~g} \mathrm{~cm}^{-3}$ a $1,228 \mathrm{~g} \mathrm{~cm}^{-3}$; resistência à compressão de 4,68 MPa a 5,82 MPa; teor de voláteis de 79,01\% a 82,25\%; teor de carbono fixo de $15,26 \%$ a $20,18 \%$; teor de cinzas de $0,38 \%$ a $2,49 \%$; poder calorífico superior de $4.571 \mathrm{kcal} \mathrm{kg}^{-1}$ a $4.716 \mathrm{kcal} \mathrm{kg}^{-1}$; e densidade energética de $5,08 \mathrm{Gcal} \mathrm{m}^{-3}$ a $5,84 \mathrm{Gcal} \mathrm{m}^{-3}$. Os briquetes produzidos a partir de $P$. nigra apresentaram melhor qualidade energética, seguidos dos briquetes de $P$. edulis, $P$. bambusoides e $B$. vulgaris. Diante dos resultados, pode-se aferir que as quatro espécies de bambu são matérias-primas alternativas para a geração de energia.

PALAVRAS-CHAVES: Bambusa vulgaris, Phyllostachys bambusoides, Phyllostachys edulis, Phyllostachys nigra, combustíveis renováveis.

Bamboo species are perennial plants, and their growing harmonizes with the principles of sustainability, due to their fast growth and annual stalk production (Pereira \& Beraldo 2007). Also, they are considered ideal crops for the rural development in developing countries. The United Nations consider the production and use of bamboo relevant to many goals of sustainable development (Van Dam et al. 2018). The potential of this abundant neutral

1. Received: Jul. 27, 2018. Accepted: Oct. 10, 2018. Published: Mar. 18, 2019. DOI: 10.1590/1983-40632019v4954178. 2. Universidade do Estado de Santa Catarina, Departamento de Engenharia Florestal, Setor de Ciências Agroveterinárias, Lages, SC, Brasil.E-mail/ORCID: martha.brand@udesc.br/0000-0001-5438-2081, dani_nones@hotmail.com/0000-0002-5547-3855, espacoa.design@gmail.com/0000-0002-237̄7-9622.

3. Centro Universitário Facvest, Departamento de Engenharias, Lages, SC, Brasil.

E-mail/ORCID: balduino.ailton@gmail.com/0000-0002-5621-154X. 
$\mathrm{CO}_{2}$ resource must be exploited to provide future generations with essential and basic needs products (Van Dam et al. 2018).

In Brazil, the research and technological development related to sustainable management, cultivation, environmental services and uses of bamboo products and by-products, as well as the incentive for cultivation and use of bamboo by family farming and the stimulation of the national and international trade of bamboo products and by-products, were instituted by the law $\mathrm{n}^{\mathrm{o}} .12,484$ (Brasil 2011), which organizes the national policy to encourage the sustainable management and cultivation of bamboo.

The Brazil's climatic diversity demands the research for species that can adapt to both cold, mainly where frost occurs, and hot regions. According to Balduino Junior et al. (2016), in South Brazil, the bamboo planted area is still small, but on the coastline, where there is no frost, the species Bambusa vulgaris Schrad. Ex J.C.Wendl. is promising. However, technical information is needed to subsidize investors who are interested in expanding the raw material supply base for energy generation in the different regions of the country.

In the highlands of the Santa Catarina state, species of the Phyllostachys Siebold \& Zucc. genus are being cultivated in experimental plantations, mainly in Japanese communities. The Japanese community of Frei Rogério is an example where species of this genus have been planted by farmers and are already being sold to the food, matchstick and barbecue stick industries. Some of the stalks, mainly the upper parts, remain in the field as waste, though.

Bamboo species have a potential for bioenergy production, because of their high cellulose and hemicellulose contents, high calorific value and low ash content (Rambo et al. 2015). Thus, considering the growth potential of these species, the search for new energy generation uses for bamboo crops and their residues is very important (Scurlock et al. 2000).

In addition, briquetting is one of the alternatives for energy production. It consists of the densification of the biomass for the production of a biofuel known as briquette. The significant increase in biomass density results in a better handling, increases the calorific value by volume, reduces transport costs and produces a uniform, clean and stable fuel (Granada et al. 2002). Moreover, briquettes can be produced from both the whole stalks and from the residues of other uses.

For those reasons, this study aimed to evaluate the potential use of four bamboo species for briquette production.

\section{MATERIAL AND METHODS}

The following species were analyzed in this study: Bambusa vulgaris Schrad. Ex J.C.Wendl., Phyllostachys bambusoides Siebold \& Zucc., Phyllostachys edulis (Carrière) J. Houz. and Phyllostachys nigra (Lodd. Ex Lindl.) Munro. Five individuals of each species were randomly collected (Table 1) and samples of 1.0-1.5 $\mathrm{m}$ in length were acquired at the lower, medium and higher part of the stalks. The stalks of all species under analysis were three years old at the time of collection.

$B$. vulgaris specimens were collected at an experimental farm owned by the Universidade Federal de Santa Catarina, in Florianópolis (27\%41'03.7'S and $48^{\circ} 32^{\prime} 33.8^{\prime \prime} \mathrm{W}$ ), while the other specimens (P. bambusoides, P. edulis and P. nigra) were collected in Frei Rogério $\left(27^{\circ} 13^{\prime} 19.5^{\prime}\right.$ 'S and 5044'13.4”W), both in the Santa Catarina state, Brazil.

Table 1. Dendrometric characteristics of the stalks.

\begin{tabular}{|c|c|c|c|c|c|c|c|}
\hline \multirow{2}{*}{ Species } & \multirow{2}{*}{ Treatment } & \multicolumn{5}{|c|}{ Individuals } & \multirow{2}{*}{ Mean } \\
\hline & & 1 & 2 & 3 & 4 & 5 & \\
\hline \multirow{2}{*}{ Bambusa vulgaris } & DBH $(\mathrm{cm})$ & 9.00 & 10.50 & 7.30 & 10.50 & 11.00 & 9.66 \\
\hline & Height (m) & 18.00 & 13.00 & 12.00 & 16.00 & 16.50 & 15.10 \\
\hline \multirow{2}{*}{ Phyllostachys bambusoides } & DBH $(\mathrm{cm})$ & 8.00 & 7.00 & 8.00 & 9.00 & 8.00 & 8.00 \\
\hline & Height (m) & 15.00 & 13.00 & 12.50 & 16.00 & 15.00 & 14.30 \\
\hline \multirow{2}{*}{ Phyllostachys edulis } & $\mathrm{DBH}(\mathrm{cm})$ & 7.95 & 7.65 & 8.80 & 8.30 & 8.10 & 8.16 \\
\hline & Height (m) & 16.40 & 16.80 & 16.84 & 16.55 & 16.44 & 16.61 \\
\hline \multirow{2}{*}{ Phyllostachys nigra } & DBH $(\mathrm{cm})$ & 8.28 & 7.64 & 7.32 & 7.96 & 7.16 & 7.67 \\
\hline & Height (m) & 15.90 & 15.60 & 15.80 & 15.86 & 15.60 & 15.75 \\
\hline
\end{tabular}

$\mathrm{DBH}=$ diameter at $1.30 \mathrm{~m}$ above the ground 
The B. vulgaris and P. bambusoides species were analyzed in 2015, and $P$. edulis and P. nigra between 2016 and 2017. However, the experimental procedures were the same for all the species.

The briquettes were produced using a pilot hydraulic piston briquette machine, with a heating temperature of $120^{\circ} \mathrm{C}$. Each briquette was produced in $10 \mathrm{~min}$ (Furtado et al. 2010). In the first $8 \mathrm{~min}$, the applied pressure was $50 \mathrm{bar}$, and, in the last $2 \mathrm{~min}$, the pressure was raised to 95 bar, allowing the internal bonding and the consolidation of the briquettes to occur.

First, the moisture content of the sawdust was determined. Then, eight briquettes, with $35 \mathrm{~mm}$ in diameter and around $50 \mathrm{~mm}$ in length, were made for each treatment (analyzed species). The sawdust mass used for the production of each briquette was $50 \mathrm{~g}$ (wet basis). The particle size distribution of each briquette was $88 \%$ (44 g) of the briquette mass consisting of particles between $3.35 \mathrm{~mm}$ and $15.99 \mathrm{~mm}$ and $12 \%(6 \mathrm{~g})$ with particles between $0.25 \mathrm{~mm}$ and $3.34 \mathrm{~mm}$ (CEN 2010).

Next, the following properties of the briquettes were analyzed: moisture content (wet basis) (ABNT 2003), bulk density (mass/volume ratio of each briquette) and compression strength, adapted from the NBR 7222 standard (ABNT 2011), as described by Brand et al. (2017).

The compression strength (or crush resistance or hardness) is the maximum crushing load that a briquette can withstand before cracking or breaking. In this analysis, each briquette is placed between two flat and parallel platens, whose facial areas are larger than the projected area of the briquette. An increasing load is applied at a constant rate $\left(2 \mathrm{~mm} \mathrm{~min}^{-1}\right)$ until the tested specimen fails by cracking or breaking. The load at fracture is read from a recorded stress-strain curve, which is the compression strength reported as force or stress. In this way, the compression strength of the briquettes is determined by the diametrical compression test (Brand et al. 2017).

The maximum crushing load of the briquettes was calculated by the following equation: Load = $(2 \times \mathrm{F}) /(\pi \times \mathrm{d} \times \mathrm{L})$, where load is the maximum crushing load (MPa), $F$ the force in Newtons, $d$ the briquette diameter in millimeters and $L$ the briquette length in millimeters.

After that, the briquettes were used to measure the proximate analysis, the gross calorific value and the energy density in the briquettes. The proximate analysis was performed on a thermogravimetric scale with a temperature of $900{ }^{\circ} \mathrm{C}$ for the determination of the volatile content and $700{ }^{\circ} \mathrm{C}$ for the ash content (ASTM 2013). The gross calorific value analysis was performed in triplicate in a calorimetric pump (model IKA C2000) (DIN 2003). The energy density was calculated by multiplying the gross calorific value by the bulk density of the briquettes.

Finally, the obtained data were submitted to the Anova and the Scott-Knott test at $95 \%$ of significance, using the Sisvar software. For the study of the correlation between the physical and the energetic properties, the Pearson's correlation coefficient (r) was used, which reflects the intensity of a linear relationship between two data sets. Moreover, a regression analysis of the data obtained from the compression strength and the bulk density analyses was carried out, resulting in the establishment of the adjustment equation and the calculation of the $\mathrm{R}^{2}$ for both properties.

\section{RESULTS AND DISCUSSION}

The results obtained for the physical and energetic properties of the sawdust and the briquettes of each analyzed bamboo species are shown in Table 2.

The moisture content measured before the compaction process indicated that the B. vulgaris, $P$. bambusoides and $P$. edulis species were in a homogeneous condition, presenting the highest values, while $P$. nigra showed the lowest value. In general, the analyzed species presented a moisture content within the expected values required for compaction.

Dias et al. (2012) and Niedziółka et al. (2015) point out that the biomass subjected to the compaction process must have a moisture content between $5 \%$ and $15 \%$, since this range results in a dense, stable and durable product. Dias et al. (2012) also claim that water eases the gelatinization of the starch, the protein fragmentation and the fiber dissolution during the densification process. On the other hand, the water overflow can lead to compaction and clogging during the machine feeding process.

The moisture content of the briquettes is an important parameter, because it directly affects the energetic balance of the densification. The lower the moisture content, the higher is the heat production per mass unit (Vale et al. 2000). The results showed that all the analyzed briquettes had 
Table 2. Physical and energetic properties of the sawdust and briquettes of four bamboo species.

\begin{tabular}{lcccccccc}
\hline \multicolumn{1}{c}{ Species } & MCs & MCb & BD & CS & VC & FCC & AC & GCV \\
\hline Bambusa vulgaris & $10.80 \mathrm{a}^{*}$ & $8.06 \mathrm{a}$ & $1.109 \mathrm{c}$ & $4.96 \mathrm{~b}$ & $82.25 \mathrm{a}$ & $15.26 \mathrm{~d}$ & $2.49 \mathrm{a}$ & $4,571 \mathrm{~b}$ \\
Phyllostachys bambusoides & $10.57 \mathrm{a}$ & $7.51 \mathrm{~b}$ & $1.170 \mathrm{~b}$ & $4.68 \mathrm{~b}$ & $81.88 \mathrm{a}$ & $17.28 \mathrm{c}$ & $0.90 \mathrm{~b}$ & $4,694 \mathrm{a}$ \\
Phyllostachys edulis & $10.80 \mathrm{a}$ & $3.92 \mathrm{~d}$ & $1.221 \mathrm{a}$ & $5.82 \mathrm{a}$ & $80.62 \mathrm{~b}$ & $19.01 \mathrm{~b}$ & $0.38 \mathrm{c}$ & $4,670 \mathrm{a}$ \\
Phyllostachys nigra & $7.78 \mathrm{~b}$ & $5.23 \mathrm{c}$ & $1.238 \mathrm{a}$ & $5.79 \mathrm{a}$ & $79.01 \mathrm{c}$ & $20.18 \mathrm{a}$ & $0.81 \mathrm{~b}$ & $4,716 \mathrm{a}$ \\
\hline CV & 14.74 & 11.31 & 3.23 & 10.83 & 1.37 & 6.58 & 46.44 & 2.34 \\
\hline
\end{tabular}

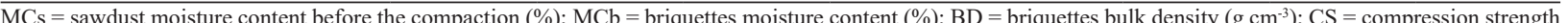
$(\mathrm{MPa}) ; \mathrm{VC}=$ volatile content $(\%) ; \mathrm{FCC}=$ fixed carbon content $(\%) ; \mathrm{AC}=$ ash content $(\%) ; \mathrm{GCV}=$ gross calorific value $\left(\mathrm{kcal} \mathrm{kg}^{-1}\right) ; \mathrm{CV}=$ coefficient of variation $(\%)$.

* Means followed by the same letter in the columns do not differ statistically at $5 \%$ of probability by the Scott-Knott test.

moisture contents lower than $10 \%$, and that P. edulis and P. nigra presented higher moisture reductions, when comparing the moisture content of the sawdust to the briquettes.

The Pearson's correlation analysis indicated a strong and negative correlation among the moisture content, the compression strength and the bulk density of the briquettes (Table 3), what allows assuring that briquettes with lower moisture contents will have higher bulk densities and compression strength.

The bulk density analysis of the briquettes showed that the values differed statistically among the analyzed species. P. edulis and P. nigra presented high values, but, in general, they were higher for the Phyllostachys genus, when compared to the $B$. vulgaris species.

The higher the bulk density, the higher is the energy/volume ratio (Demirbas \& Sahin-Demirbas 2004). In addition, high-density products (500-1,200 $\mathrm{kg} \mathrm{m}^{-3}$ ) have a better storage, transportation and handling performance than low-density products.

Sette Júnior et al. (2017), in a recent briquette production study using the Phyllostachys aurea species, obtained a bulk density of $1.160 \mathrm{~g} \mathrm{~cm}^{-3}$.

Table 3. Pearson's correlation coefficient among the moisture content, bulk density, compression strength and energy density of bamboo briquettes.

\begin{tabular}{|c|c|c|c|c|c|c|c|c|}
\hline Variables & $\mathrm{MC}$ & CS & BD & ED & $\mathrm{VC}$ & FCC & $\mathrm{AC}$ & GCV \\
\hline $\mathrm{MC}$ & - & & & & & & & \\
\hline $\mathrm{CS}$ & -0.60 & - & & & & & & \\
\hline $\mathrm{BD}$ & -0.67 & 0.68 & - & & & & & \\
\hline ED & - & - & 0.95 & - & & & & \\
\hline $\mathrm{VC}$ & - & - & -0.74 & -0.77 & - & & & \\
\hline FCC & - & - & 0.78 & 0.79 & -0.91 & - & & \\
\hline $\mathrm{AC}$ & - & - & -0.56 & -0.55 & 0.35 & -0.71 & - & \\
\hline GCV & - & - & 0.27 & 0.55 & -0.29 & 0.31 & -0.21 & - \\
\hline
\end{tabular}

Their result is similar to the one found in this study for the Phyllostachys genus. The bulk density of the briquettes showed a strong and positive correlation with the energy density and the fixed carbon content, and a strongly negative correlation with the volatile and the ash contents (Table 3 ).

The $P$. edulis and $P$. nigra briquettes had the highest values of compression strength, but all the analyzed species presented high values. In a previous research, Dias Junior et al. (2014), studying briquettes made $100 \%$ of Bambusa spp. particles, obtained a compression strength of $7.88 \mathrm{MPa}$, which is higher than the values observed in this study for all the analyzed species.

In contrast, Sette Júnior et al. (2017) found compression strength values of $2.07 \mathrm{MPa}$, when studying briquettes produced with $P$. aurea, which are lower than the ones obtained in this study for B. vulgaris and the three Phyllostachys species. Brand et al. (2017), analyzing this variable in briquettes produced from rice residues (a monocot but grassy plant), obtained values of $2.37 \mathrm{MPa}$ for bark and $2.89 \mathrm{MPa}$ for straw.

The regression analysis between bulk density and compression strength presented a correlation coefficient $\left(\mathrm{R}^{2}\right)$ of 0.47 (Figure 1). Dias Junior et al. (2014) obtained an $\mathrm{R}^{2}$ of 0.60 for the same correlation, being higher than the one observed in this study, but it indicates a positive correlation between the variables. In addition to the correlation presented in Figure 1, the Pearson's correlation coefficient was 0.68 (Table 3).

Briquettes with a high compression strength have advantages such as the reduction of damages during the handling, packing, transport and storage stages, or even during their energetic use by reducing its fragmentation (Freitas et al. 2016).

By analyzing the volatile content, $B$. vulgaris had the highest value, which did not differ statistically from $P$. bambusoides. For the fixed carbon content, all 


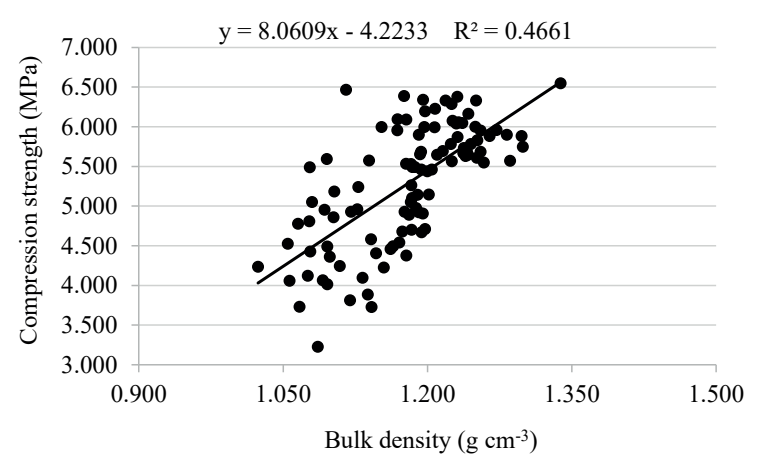

Figure 1. Correlation between the compression strength and bulk density of bamboo briquettes.

the species differed statistically, and P. nigra showed the highest value. In relation to the ash content, the highest value was presented by the $B$. vulgaris briquette, while the $P$. bambusoides and $P$. nigra briquettes were similar to each other. In general, the briquettes produced with the Phyllostachys genus showed the lowest ash contents.

When comparing the results of this study to the ones observed in previous researches with $B$. vulgaris (Table 4), the volatile content was higher, while the ash content, the fixed carbon content and the gross calorific value were lower. The proximate analysis showed that the chemical composition found in the literature for $P$. aurea was the same as the one obtained for $P$. bambusoides in this study. Moreover, the gross calorific value of the briquettes in this study was higher than the ones found in the literature.

Based on the proximate analysis of the briquettes, it can be said that the burning rate will be higher for the B. vulgaris and P. bambusoides briquettes, because they have a lower amount of residual carbon, what makes them burn at a slower rate. Furthermore, the remaining amount of residue after the burning process will be bigger for the $B$. vulgaris briquettes, as they presented a higher ash content than the Phyllostachys genus.
In relation to the gross calorific value, the species of the Phyllostachys genus had the highest values and did not differ statistically from each other. The results showed that the gross calorific value of the four analyzed bamboo species are similar to the average $\left(4,673 \mathrm{kcal} \mathrm{kg}^{-1}\right)$ of the different Pinus spp. materials (bark, chip and sawdust) that were analyzed by Furtado et al. (2010). Having in mind that the Pinus genus is widely used in the production of briquettes in Brazil, this comparison proves itself to be valid and important.

The ash content represents the inert and non-combustible fraction of the sample and, when it presents high values, the gross calorific value decreases (Furtado et al. 2010). In this study, the Pearson's correlation coefficient between these variables was -0.21 , which is a negative but low correlation (Table 3 ).

The energy density of the bamboo briquettes was high and the Phyllostachys genus showed the highest energy densities. However, all the species differed statistically from each other (Figure 2). The Pearson's correlation coefficient indicated that the bulk density of the briquettes influenced the energy density more than the gross calorific value, being both coefficients positive (Table 3 ). The correlation between the bulk density and the fixed carbon content was also positive, and the energy density had a strong negative correlation with the volatile and the ash contents.

The energy densities of the Phyllostachys briquettes were higher than the ones observed by Sette Júnior et al. (2017) (Table 5). When comparing the energy densities of the briquettes of the analyzed species with the ones of other biomass types, $B$. vulgaris and $P$. bambusoides presented higher energy densities, except for coffee bark briquettes (Protásio et al. 2011). The energy densities of the $P$. edulis and P. nigra briquettes were higher than the ones found in the literature.

Table 4. Energetic properties of bamboo species obtained in the literature.

\begin{tabular}{lccccl}
\hline \multicolumn{1}{c}{ Species } & VC & FCC & AC & GCV & \multicolumn{1}{c}{ Source } \\
\hline Bambusa spp. & 81.00 & 16.40 & 2.60 & - & Dias Junior et al. (2014) \\
Bambusa vulgaris var. vulgaris & 73.95 & 18.96 & 7.09 & - & Amaral et al. (2015) \\
Bambusa vulgaris & 74.70 & 22.80 & 2.50 & 4,667 & Sette Júnior et al. (2016) \\
Bambusa tuldoides & 75.20 & 21.80 & 3.00 & 4,515 & Sette Júnior et al. (2016) \\
Phyllostachys aurea & 81.50 & 17.60 & 0.90 & 4,404 & Sette Júnior et al. (2017) \\
\hline VC $=$ volatile content (\%); FCC: fixed carbon content (\%); AC: ash content (\%); GCV = gross calorific value $\left(\mathrm{kcal}_{\mathrm{kg}}^{-1}\right)$. &
\end{tabular}




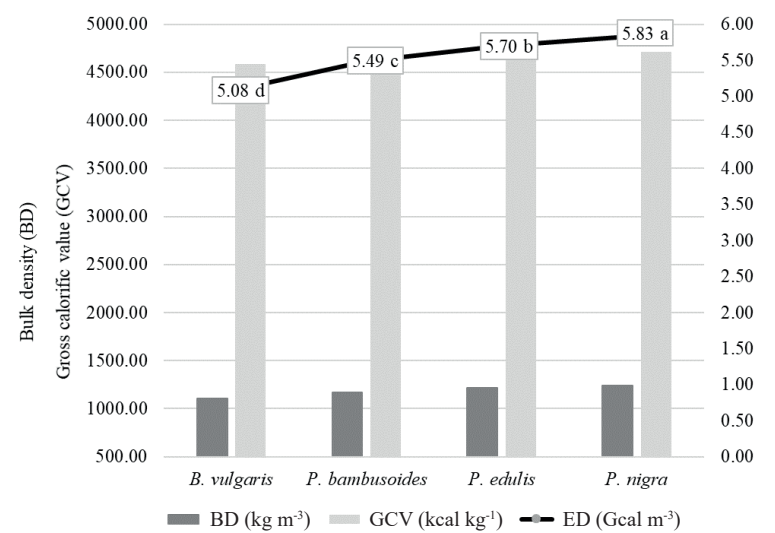

Figure 2. Relation between the energy density with bulk density and gross calorific value of briquettes of four bamboo species.

Table 5. Energy density of briquettes with different biomass types.

\begin{tabular}{lcl}
\hline \multicolumn{1}{c}{ Briquettes } & $\begin{array}{c}\text { Energy density } \\
\left(\mathrm{Gcal} \mathrm{m}^{-3}\right)\end{array}$ & \multicolumn{1}{c}{ Source } \\
\hline Coffee husk & 5.69 & Protásio et al. (2011) \\
Maize harvest residues & 4.22 & Protásio et al. (2011) \\
Eucalyptus sawdust & 4.17 & Protásio et al. (2011) \\
Cupressus lusitanica & 4.99 & Almeida et al. (2015) \\
Pinus & $4.03-4.09$ & Souza \& Vale (2016) \\
Tauari & $3.93-4.11$ & Souza \& Vale (2016) \\
Cumaru & $4.50-4.60$ & Souza \& Vale (2016) \\
Rice husk & $3.11-3.42$ & Souza \& Vale (2016) \\
Cane bagasse & $3.95-4.04$ & Souza \& Vale (2016) \\
Physic nut pie & $3.69-4.14$ & Souza \& Vale (2016) \\
Phyllostachys aurea & 5.13 & Sette Júnior et al. (2017) \\
\hline
\end{tabular}

\section{CONCLUSIONS}

1. The briquettes produced with the four bamboo species (Bambusa vulgaris, Phyllostachys bambusoides, Phyllostachys edulis and Phyllostachys nigra) presented satisfactory physical and energetic properties;

2. Among the analyzed species, the P. nigra briquettes showed the best energy quality, followed by the P. edulis, P. bambusoides and B. vulgaris briquettes.

\section{REFERENCES}

ALMEIDA, C. C. F. de et al. Energetic quality of wood and briquettes produced from Cupressus lusitanica Mill. Scientia Forestalis, v. 43, n. 108, p. 1003-1011, 2015.
AMARAL, P. M. et al. Caracterização química, física e mecânica de briquetes de duas variedades de bambu. Instituto Florestal Magazine, v. 27, n. 1, p. 73-81, 2015.

AMERICAN SOCIETY FOR TESTING AND MATERIALS (ASTM). ASTM D-1762: standard test method for chemical analysis of wood charcoal. West Conshohocken: American Society for Testing and Materials, 2013.

ASSOCIAÇÃO BRASILEIRADE NORMAS TÉCNICAS (ABNT). NBR 14929: wood: determination of moisture of chips: method by drying in oven-dried. Rio de Janeiro: ABNT, 2003.

ASSOCIAÇÃO BRASILEIRADE NORMAS TÉCNICAS (ABNT). NBR 7222: concrete and mortar: determination of the tension strength by diametrical compression of cylindrical test specimens. Rio de Janeiro: ABNT, 2011.

BALDUINO JUNIOR, A. L. et al. Energetic potential of bamboo culms for industrial and domestic use in southern Brazil. Ciência Rural, v. 46, n. 11, p. 1963-1968, 2016.

BRAND, M. A. et al. Production of briquettes as a tool to optimize the use of waste from rice cultivation and industrial processing. Renewable Energy, v. 111, n. 1, p. 116-123, 2017.

BRASIL. Lei $n^{\circ} 12.484$, de 08 de setembro de 2011: dispõe sobre a política nacional de incentivo ao manejo sustentado e ao cultivo do bambu e dá outras providências. 2011. Available at: <https://www.planalto.gov.br/ ccivil_03/_ato2011-2014/2011/lei/112484.htm>. Access on: 12 Jun. 2017.

DEMIRBAS, A.; SAHIN-DEMIRBAS, A. Y. S. E. Briquetting properties of biomass waste materials. Energy Sources, v. 26, n. 1, p. 83-91, 2004.

DEUTSCHES INSTITUT FÜR NORMUNG (DIN). DIN 51900: 1-3: testing of solid and liquid fuels: determining the gross calorific value of solid and liquid fuels using the bomb calorimeter, and calculation of net calorific value: part 1-3. Berlin: DIN, 2003.

DIAS JÚNIOR, A. F. et al. Caracterização de briquetes produzidos com resíduos agroflorestais. Pesquisa Florestal Brasileira, v. 34, n. 79, p. 225-234, 2014.

DIAS, J. M. C. de S. et al. Produção de briquetes e péletes a partir de resíduos agrícolas, agroindustriais e florestais. Brasília, DF: Embrapa, 2012.

EUROPEAN COMMITTEE FOR STANDARDIZATION (CEN). EN 15149-1: solid biofuels: determination of particle size distribution. Part 1: oscillating screen method using sieve apertures of $1 \mathrm{~mm}$ and above. Brussels: CEN, 2010. 
FREITAS, A. J. et al. Efeito da pressão e do tempo de compactação nas propriedades de briquetes de resíduos madeireiros de paricá. Nativa, v. 4, n. 6, p. 380-385, 2016.

FURTADO, T. S. et al. Variáveis do processo de briquetagem e qualidade de briquetes de biomassa florestal. Pesquisa Florestal Brasileira, v. 30, n. 62, p. 101-106, 2010.

GRANADA, E. et al. Fuel lignocellulosic briquettes, die design and products study. Renewable Energy, v. 27, n. 4, p. 561-573, 2002.

NIEDZIÓŁKA, I. et al. Assessment of the energetic and mechanical properties of pellets produced from agricultural biomass. Renewable Energy, v. 76, n. 1, p. 312-317, 2015.

PEREIRA, M. A. R.; BERALDO, A. L. Bambu de corpo e alma. Bauru: Canal 6, 2007.

PROTÁSIO, T. de P. et al. Compactação de biomassa vegetal visando à produção de biocombustíveis sólidos. Pesquisa Florestal Brasileira, v. 31, n. 68, p. 273-283, 2011.

RAMBO, M. K. D. et al. Analysis of the lignocellulosic components of biomass residues for biorefinery opportunities. Talanta, v. 144, n. 1, p. 696-703, 2015.
SCURLOCK, J. M. O. et al. Bamboo: an overlooked biomass resource? Biomass and Bioenergy, v. 19, n. 4, p. 229-244, 2000.

SETTE JÚNIOR, C. R. et al. Production and characterization of bamboo pellets. Bioscience Journal, v. 32, n. 4, p. 922930, 2016.

SETTE JÚNIOR, C. R. et al. Characterization of biomass, charcoal, and briquette of Phyllostachys aurea Carr. ex A. \& C. Scientia Forestalis, v. 45, n. 116, p. 619-628, 2017.

SOUZA, F. de; VALE, A. T. do. Densidade energética de briquetes de biomassa lignocelulósica e sua relação com os parâmetros de briquetagem. Pesquisa Florestal Brasileira, v. 36, n. 88, p. $405-413,2016$.

VALE, A. T. do et al. Produção de energia do fuste de Eucalyptus grandis Hill Ex-Maiden e Acacia mangium Willd. em diferentes níveis de adubação. Cerne, v. 6, n. 1, p. 83-88, 2000.

VAN DAM, J. E. G. et al. Bamboo production for industrial utilization. In: ALEXOPOULOU, E. (Ed.). Perennial grasses for bioenergy and bioproducts. Cambridge: Academic Press, 2018. p. 175-216. 